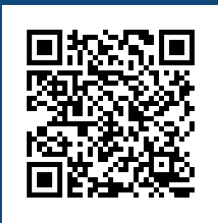

Keywords:

Thermal effect

Thermal degradation of biomass

Carbonization

Heat action on wood

Historic:

Received 07/10/2018

Accepted 12/03/2019

Correspondence: ananiasjr@usp.br

Ananias Francisco Dias Júnior ${ }^{1+}$, Carlos Rogério Andrade ${ }^{2 a}$, Thiago de Paula Protásio ${ }^{3 a}$, José Otávio Brito ${ }^{5 a}$, Paulo Fernando Trugilho ${ }^{4 a}$, Michel Picanço Oliveira ${ }^{1 b}$, Graziela Baptista Vidaurre Dambroz ${ }^{\text {lc }}$

\title{
THERMAL PROFILE OF WOOD SPECIES FROM THE BRAZILIAN SEMI-ARID REGION SUBMITTED TO PYROLYSIS
}

DIAS JÚNIOR, A. F.; ANDRADE, C. R.; PROTÁSIO, T. P.; BRITO, J. O.; TRUGILHO, P. F; OLIVEIRA, M. P; DAMBROZ, G. B. V. Thermal profile of wood species from the brazilian semi-arid region submitted to pyrolysis. CERNE, v. 25, n. I, p. 44-53, 2019.

\section{HIGHLIGHTS}

We analyzed native and endangered species of the Brazilian semi-arid region.

The thermal profile of the species was questioned for energy generation.

Mimosa tenuiflora and Poincianella pyramidalis were the most suitable wood species for sustainable charcoal production.

The energy characteristics will allow the efficient management of the species in mixed plantations for this purpose.

\section{ABSTRACT}

The objective of this study was to evaluate the thermal decomposition profile of 10 wood species from the semi-arid region of Brazil using thermogravimetric analysis (TGA) to investigate their potential as biomass energy sources. First, flash carbonization was carried out in a muffle furnace, in which wood samples were heated to a maximum temperature of $500^{\circ} \mathrm{C}$, and the product yields were determined. The chemical analysis of the wood of each species for the determination of extractive, lignin and ash contents was performed. TGA was performed using sawdust samples heated at $10^{\circ} \mathrm{C} \cdot \mathrm{min}^{-1}$ up to $625^{\circ} \mathrm{C}$ under a nitrogen atmosphere at a flow rate of $50 \mathrm{~mL} \cdot \mathrm{min}^{-1}$. The thermal decomposition profile was used to evaluate which wood species was more thermally stable. Mimosa tenuiflora and Poincianella pyramidalis woods were the most suitable as biomass energy sources for charcoal production because of their thermal stability and satisfactory carbonization yields. The thermal stability of the 10 wood samples was confirmed by the analysis of the carbonization yields.

' Federal University of Espírito Santo, Jerônimo Monteiro, Espirito Santo, Brazil - ORCID:0000-000 I-9974-0567ª, 0000-0001-9241-0194b, 0000-0001-9285-7105c

${ }^{2}$ Federal University of Goias, Jataí, Goías, Brazil - ORCID: 0000-000 I-7243-3073a

${ }^{3}$ Federal Rural University of Amazonia, ORCID: 0000-0002-5560-8350 


\section{INTRODUCTION}

The semi-arid biome known as Caatinga covers most of the Northeastern region of Brazil. This biome is dominated by one of the few types of vegetation unique to Brazil, harboring several endemic plant and animal species (Silva and Oren, 1997). According to Oliveira et al. (2006) and Paes et al. (20I2), the demand for new biomass energy products has increased in the Brazilian semi-arid region, enhancing the interest in native vegetation as a source for firewood and charcoal production. Despite the importance of Caatinga vegetation as an energy source, there is a lack of information about its native species and their energy potential, specifically regarding charcoal production for industrial and domestic uses (Dias Júnior et al., 2018). Some Caatinga species have already been studied for energy, such as Mimosa tenuiflora, Piptadenia stipulacea, Caesalpinia pyramidalis, Aspidosperma pyrifolium among others (Carneiro, et al., 2013; Dias Júnior et al., 20l8). However, the knowledge of a greater number of species can facilitate the management practices in the region in order to obtain raw material for various industrial activities. Thus, knowledge of the chemical composition and thermal behavior of wood species sourced from forest management areas is essential for sustainable energy generation in regional enterprises. This effort is driven by the need to restore this biome, threatened with extinction, using vegetation restoration approaches and, at the same time, to meet the demands of wood industries (Kelty, 2006; Amazonas et al., 2018).

Pyrolysis of wood consists in the heating of wood to temperatures of up to $500^{\circ} \mathrm{C}$ in a nonoxidizing atmosphere and has as one of its products a solid material rich in carbon, called charcoal. Its volatile fraction consists of non-condensable and condensable gases, which compose the pyroligneous liquid (Jesus et al., 20 I8; Demirbas, 2003; Guillén et al., 200 I). Pyrolysis is a complex process that consists of a series of chemical reactions, accompanied by heat and mass transfer (Yang et al., 2007). The pyrolysis of any biomass, including wood, can be considered as the thermal decomposition of the three main biomass components (hemicellulose, cellulose, and lignin) and the loss of water.

Cellulose, a polysaccharide formed exclusively by $\beta$-D-anhydroglucopyranose units bound by glycosidic bonds, is the main chemical constituent of wood, accounting for $42 \%$ of its dry matter (Sjöström, 1993; Rowell et al., 2005). This polymer decomposes at temperatures between 315 and $400^{\circ} \mathrm{C}$ (Yang et al., 2007). Hemicelluloses represent, on average, 20 to $30 \%$ of wood dry mass (Sjöström, 1993). They are generally amorphous, low molecular weight polymers, consisting of a central chain of repeating units from which side chains branch out (Sjöström, 1993; Rowell et al., 2005). Hemicellulose thermal degradation occurs between 190 and $360^{\circ} \mathrm{C}$ (Shen et al., 2010). Finally, lignins are threedimensional, amorphous, branched macromolecules that present phenylpropane as the basic unit bound by ether $(\mathrm{C}-\mathrm{O}-\mathrm{C})$ and carbon-carbon $(\mathrm{C}-\mathrm{C})$ bonds (Rowell et al., 2005). Its thermal decomposition starts at approximately $100^{\circ} \mathrm{C}$ and continues until about $900^{\circ} \mathrm{C}$ (Müller-Hagedorn et al., 2003; Yang et al., 2007).

Due to the complexity of the conversion process from wood to energy, it is important to assess of its thermal decomposition, mainly considering that wood is heterogeneous material. For this, it is necessary to use techniques that facilitate the understanding of the process. The thermogravimetric analysis (TGA) accompanies the of the sample as a function of time, it being possible to determine the temperature when the thermal degradation starts and when it is most intense. Also provide the amount of residue is produced at a certain temperature, being of this important tool when you want to select species for energy purposes (Carneiro et al., 2013; Araújo et al., 2016; Azizi et al., 2017; Martinez et al., 2018; Fernandez et al., 2019).

In 2006, the Plants of the Northeast Association (APNE) started field, technological, and social studies in rural settlements of the semi-arid region of Pernambuco, Brazil, to promote the sustainable forest management of the Caatinga. The set of actions, supported by several partnerships, has provided favorable socioeconomic results and the consolidation of methodologies. It is within this context that the economic activities of charcoal production and extraction of pyroligneous liquid take place. An important part of the actions includes laboratory studies to obtain basic results and support field-scale charcoal and pyroligneous liquid production (Dias Júnior et al., 2018).

Information on materials that are potential sources of biomass energy (for combustion and carbonization) is fundamental for the selection of more suitable species, aiming at the optimization and increased efficiency of processes for input generation. Considering the great challenges of managing overexploited biomes, such as the Caatinga, studies on wood properties are relevant for the successful selection of wood species and the elaboration of management plans.

With the aim of obtaining more information on the Caatinga, a biome that is characteristic of Brazil but about which there is a lack of technical and scientific information, we evaluated the thermal decomposition of ten wood species from the semi-arid region of Brazil 
by thermogravimetric analysis (TGA) in order to obtain scientifically accurate information on their thermal profile.

\section{MATERIAL AND METHODS}

Wood samples were supplied by the Plants of the Northeast Association (APNE) from forest management areas located in rural settlements in the state of Pernambuco, Brazil. Ten tree species of the Caatinga were selected, as described in Table I.

TABLE ICaatinga wood species analyzed in the study.

\begin{tabular}{|c|c|c|}
\hline Species & Popular name & Family \\
\hline $\begin{array}{c}\text { Anadenanthera colubrina var. cebil } \\
\text { (Griseb.) Altschul }\end{array}$ & $\begin{array}{l}\text { Angico-de- } \\
\text { caroço }\end{array}$ & Fabaceae \\
\hline $\begin{array}{c}\text { Poincianella pyramidalis (Tul.) L.P. } \\
\text { Queiroz }\end{array}$ & Catingueira & Fabaceae \\
\hline Cnidoscolus quercifolius Pohl & Faveleira & Fabaceae \\
\hline Piptadenia stipulacea (Benth.) Ducke & Jurema branca & Fabaceae \\
\hline Mimosa tenuiflora (Willd.) Poir. & Jurema preta & Fabaceae \\
\hline $\begin{array}{l}\text { Manihot carthaginensis subsp. glaziovii } \\
\text { (Müll.Arg.) }\end{array}$ & Maniçoba & Euphorbiaceae \\
\hline Aspidosperma pyrifolium Mart. & Pereiro & Apocynaceae \\
\hline Platycyamus regnellii Benth. & Pereira brava & Fabaceae \\
\hline Jatropha grossidentata Pax \& K. Hoffm & Quebra-faca & Euphorbiaceae \\
\hline $\begin{array}{c}\text { Commiphora leptophloeos (Mart.) } \\
\text { J.B.Gillett }\end{array}$ & $\begin{array}{l}\text { Umburana-de- } \\
\text { cambão }\end{array}$ & Burseraceae \\
\hline
\end{tabular}

Non-destructive samples (bark-to-bark) were collected from three specimens of each species at the diameter at breast height. Samples of the tree wood were removed with the help of a tread in five distinct points of the trunk.

Wood samples without the presence of bark were characterized by chemical composition analysis, in which the total extractive content was determined according to the method T-I2 05-75 of the Technical Association of the Pulp and Paper Industry (Tappi, 1975) and the Klason lignin content was determined according to TAPPI method 222 05-74 (Tappi, 1974). The ash content was determined by immediate analysis according to the method NBR 8II2 of the Brazilian Association of Technical Standards (Abnt 1986), and the higher calorific value was determined in accordance with NBR 8633 (ABNT, 1984).

For pyrolysis, $5 \pm \mathrm{I} \mathrm{g}$ of wood samples were chipped and milled in a Wiley-type mill using a 40-mesh sieve. Analysis was conducted on a Gray-King pyrolysis apparatus consisting of a glass retort inserted in an electric heating muffle furnace under inert atmosphere saturated with nitrogen gas at $500^{\circ} \mathrm{C}$. Thermocouples were placed in the reaction zone of the glass retort that contained the wood sample for temperature control. $A$ vertical $U$-tube immersed in crushed ice was used to collect the condensable gases. The procedures followed the recommendations of Dias Júnior et al. (20l8).
After pyrolysis, the mass of charcoal contained in the glass tube and the mass of pyroligneous liquid deposited in the U-tube were measured. The carbonization yields of charcoal, pyroligneous liquid, and non-condensable gases were then determined. Details of the apparatus are shown in Figure I.

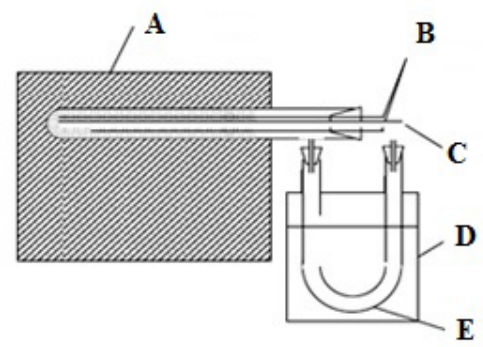

FIGURE I Gray-King pyrolysis apparatus. A = muffle furnace; $B=$ thermocouple; $C=$ opening for nitrogen gas insertion; $\mathrm{D}=$ ice container; $\mathrm{E}=\mathrm{U}$-tube for collection of pyroligneous liquid. Source: Dias Júnior et al. (2018).

TGA was performed on a Shimadzu TGA-60 under a nitrogen gas atmosphere at a constant flow of $50 \mathrm{~mL}$

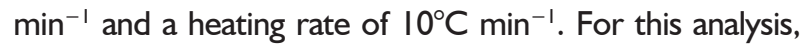
approximately $4 \mathrm{mg}$ of wood sawdust with a particle size of 200-270 mesh was used. The thermograms were obtained over a temperature range of $25^{\circ} \mathrm{C}$ (room temperature) to $625^{\circ} \mathrm{C}$. This temperature range was defined based on what is practiced in Brazil the majority of systems of production of charcoal, temperatures between 400 and $600^{\circ} \mathrm{C}$ (Carneiro et al., 2013; Pereira et al., 2013). The loss of mass for the main temperature ranges was obtained along the decomposition in relation to the initial mass analyzed.

Data were submitted to Shapiro-Wilk test for normality and Levene's test of homogeneity of variances. For analysis of variance (ANAVA), a completely randomized design with five replications per wood species was used, and the Scott Knott test at $95 \%$ probability was employed for multiple comparison of means.

\section{RESULTS}

Table 2 shows the characteristics and properties of the studied wood species. Anadenanthera colubrina, Mimosa tenuiflora, and Comminphora leptophloeos presented the highest total extractive content.

It is observed values higher than $20 \%$ of extractive content in the wood of the species studied. In contrast, for the lignin content, characteristic associated with the yield in charcoal, it is observed the greatest value for Mimosa tenuiflora. Woods of the Cnidoscolus quercifolius, Jatropha grossidentata and Comminphora leptophloeos species presented values close to $27 \%$ and the other 
TABLE 2 Basic density and chemical composition of Eucalyptus wood.

\begin{tabular}{|c|c|c|c|c|c|c|c|}
\hline Species & $\begin{array}{c}\text { TEX } \\
\text { (wt.\%) }\end{array}$ & $\begin{array}{c}\text { LIG } \\
\text { (wt.\%) }\end{array}$ & $\begin{array}{c}\text { ASH } \\
\text { (wt.\%) }\end{array}$ & $\begin{array}{c}\mathrm{HHV} \\
\left(\mathrm{MJ} \cdot \mathrm{kg}^{-1}\right)\end{array}$ & $\begin{array}{c}\mathrm{CHY} \\
(w t . \%)\end{array}$ & $\begin{array}{c}\text { PAY } \\
\text { (wt.\%) }\end{array}$ & $\begin{array}{l}\text { NCGY } \\
\text { (wt.\%) }\end{array}$ \\
\hline Anadenanthera colubrine & $20.68 \mathrm{a}$ & $24.89 c$ & $1.78 c$ & $18.70 c$ & $26.8 \mathrm{Ic}$ & $26.76 d$ & $46.42 b$ \\
\hline Standard mean error $( \pm)$ & 0.52 & 1.06 & 0.11 & 0.11 & 2.38 & 1.66 & 0.98 \\
\hline Poincianella pyramidalis & $15.15 c$ & $25.19 c$ & $2.82 \mathrm{a}$ & I7.96d & $30.0 \mathrm{lb}$ & $36.39 a$ & $33.60 \mathrm{e}$ \\
\hline Standard mean error $( \pm)$ & $0.7 \mathrm{I}$ & 0.68 & 0.29 & 0.08 & 2.20 & 1.65 & 1.01 \\
\hline Cnidoscolus quercifolius & $17.25 b$ & $27.53 b$ & $0.80 \mathrm{~d}$ & $20.46 a$ & $23.56 \mathrm{~d}$ & $34.77 b$ & $41.67 c$ \\
\hline Standard mean error $( \pm)$ & 0.95 & 0.18 & 0.02 & 0.06 & 1.98 & 1.95 & 1.55 \\
\hline Piptadenia stipulacea & $13.60 c$ & $24.91 \mathrm{c}$ & $0.45 \mathrm{e}$ & $19.28 c$ & $28.98 b$ & $37.94 a$ & $33.08 \mathrm{e}$ \\
\hline Standard mean error $( \pm)$ & 0.49 & 0.70 & 0.01 & 0.06 & 3.33 & 2.22 & 1.49 \\
\hline Mimosa tenuiflora & $23.31 \mathrm{a}$ & $32.80 \mathrm{a}$ & $0.92 d$ & $20.56 a$ & $32.72 \mathrm{a}$ & $30.77 c$ & $36.52 d$ \\
\hline Standard mean error $( \pm)$ & 0.33 & 0.60 & 0.05 & 0.08 & 3.42 & 2.35 & 1.78 \\
\hline Manihot carthaginensis & I4.64c & $23.68 c$ & $1.79 c$ & $18.35 d$ & $31.88 \mathrm{a}$ & $32.44 \mathrm{c}$ & $35.68 d$ \\
\hline Standard mean error $( \pm)$ & 2.04 & 0.81 & 0.11 & 0.11 & 1.91 & 1.28 & 2.01 \\
\hline Aspidosperma pyrifolium & $17.69 \mathrm{~b}$ & $25.3 \mathrm{Ic}$ & $0.92 d$ & $19.62 b$ & $23.27 d$ & $24.22 \mathrm{~d}$ & $52.52 \mathrm{a}$ \\
\hline Standard mean error $( \pm)$ & 0.37 & 0.28 & 0.02 & 0.05 & 5.33 & 3.32 & 0.99 \\
\hline Platycyamus regnellii & $12.59 \mathrm{c}$ & $24.86 c$ & $0.32 b$ & $19.31 \mathrm{c}$ & $32.52 a$ & $34.87 \mathrm{~b}$ & $32.6 \mathrm{le}$ \\
\hline Standard mean error $( \pm)$ & 0.55 & 0.26 & 0.02 & 0.05 & 2.37 & 1.10 & 1.36 \\
\hline Jatropha grossidentata & $16.16 \mathrm{~b}$ & $27.09 \mathrm{~b}$ & $1.05 \mathrm{~d}$ & $19.89 b$ & $29.39 b$ & $34.34 b$ & $36.27 d$ \\
\hline Standard mean error $( \pm)$ & 0.71 & 1.49 & 0.16 & 0.05 & 4.21 & 3.20 & 1.47 \\
\hline Commiphora leptophloeos & $21.25 \mathrm{a}$ & $27.04 b$ & $0.64 \mathrm{e}$ & $19.20 c$ & $28.8 \mathrm{Ib}$ & $33.09 b$ & $38.10 c$ \\
\hline Standard mean error $( \pm)$ & 0.51 & 0.24 & 0.01 & 0.06 & 4.20 & 3.49 & 1.36 \\
\hline
\end{tabular}

TEX = total extractive content; LIG = lignin content; $\mathrm{ASH}=$ ash content; $\mathrm{HHV}=$ higher heating value; $\mathrm{CHY}=$ charcoal yield; $\mathrm{PAY}=\mathrm{pyroligneous} \mathrm{liquid}$ yield; $\mathrm{NCGY}$ $=$ non-condensable gases yield. Means followed by the same letter in a column do not differ from each other by the Scott-Knott test at $95 \%$ probability. Source: Dias Júnior et al. (2018).

species had mean values close to $25 \%$ for this variable. Ash content, the Piptadenia stipulacea and Comminphora leptophloeos species presented the lowest values, which the higher mean value detected was for the Poincianella pyramidalis wood (Figure 2). The species from the Brazilian semi-arid region (Poincianella pyramidalis and Manihot carthaginensis) with higher ash content and lower lignin content showed lower higher heating value. There was a highly significant correlation between higher heating value, Klason lignin and ash contents. The proportion explained of the HHV by Klason lignin and ash content was $81 \%$.

It is observed in Table 2 that woods from the Mimosa tenuiflora, Manihot carthaginensis and Platycyamus regnelli species obtained the highest charcoal yields. For yield in pyroligneous liquid, Poincianella pyramidalis and

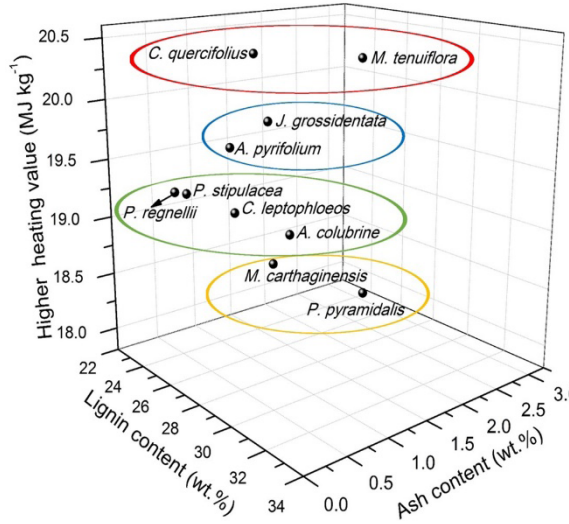

Piptadenia stipulacea presented themselves as potential species for obtaining this product. In consequence of these results, these species, together with Platycyamus regnelli, presented the lowest mean yield values in noncondensing gases.

\section{Thermogravimetric analysis}

Figure 3 shows the thermograms of the 10 analyzed wood species, in which TG curves are shown as blue lines that represent mass loss as a function of temperature and DTG curves are shown as red lines.

Table 3 presents the mass loss by thermal decomposition of each wood species according to temperature ranges. An average mass loss of $8.57 \mathrm{wt} . \%$

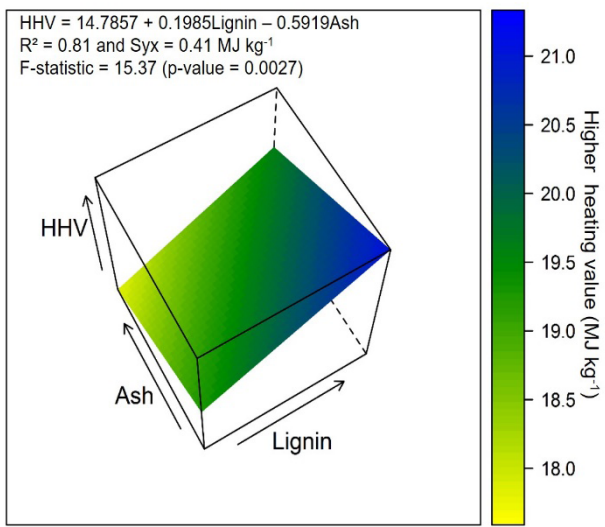

FIGURE 2 Calorific values of different wood species from the Brazilian semi-arid region. Where: the circles indicate the groups formed by the Scott-Knott test for the higher heating value (HHV). 

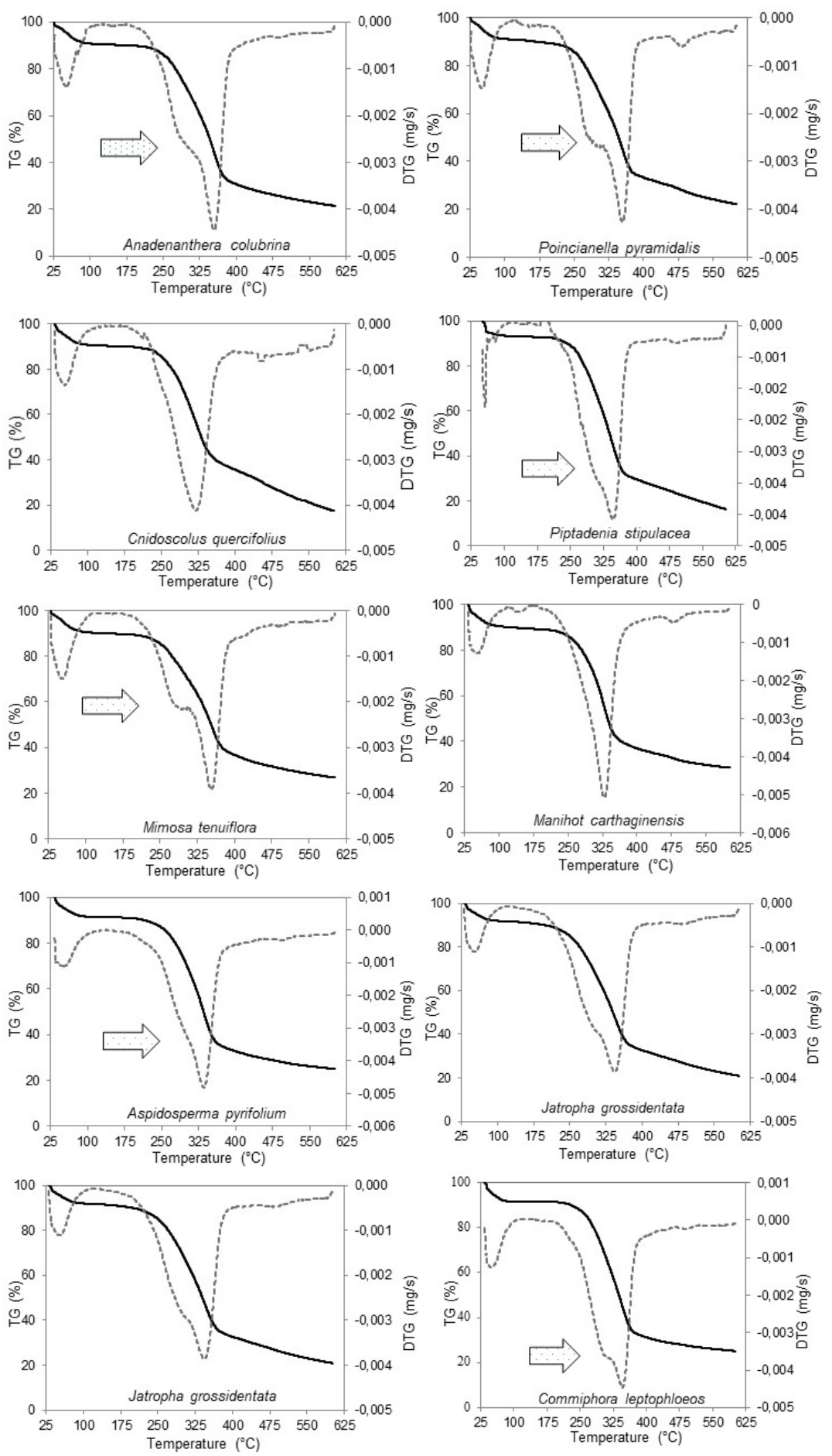

FIGURE 3 TG and DTG curves of Caatinga wood species.

was observed in the first temperature range. This phase corresponds to the drying of wood, in which the loss of water molecules linked to the cell wall occurs through the absorption of heat, characterizing an endothermic process (Pereira et al., 2013; Martinez et al., 20I8). During the pyrolysis of the wood occur two distinct stages of mass loss (Carneiro et al., 2013; Pereira et al.,
2013; Protásio et al., 20I4a), that is, evaporation of the water (drying), and in second stage, thermal degradation of the carbohydrates (between $200^{\circ} \mathrm{C}$ to $400^{\circ} \mathrm{C}$ ).

\section{DISCUSSION}

It is possible to observe that the Anadenanthera colubrina, Mimosa tenuiflora and Comminphora 
TABLE 3 Basic density and chemical composition of Eucalyptus wood.

\begin{tabular}{|c|c|c|c|c|c|c|c|}
\hline \multirow[b]{2}{*}{ Wood species } & \multicolumn{6}{|c|}{ Mass loss (wt.\%) } & \multirow{2}{*}{$\begin{array}{c}\text { Residual mass } \\
\text { (wt. \%) }\end{array}$} \\
\hline & $\begin{array}{c}25-100 \\
\left({ }^{\circ} \mathrm{C}\right)\end{array}$ & $\begin{array}{c}100-200 \\
\left({ }^{\circ} \mathrm{C}\right)\end{array}$ & $\begin{array}{c}200-300 \\
\left({ }^{\circ} \mathrm{C}\right)\end{array}$ & $\begin{array}{c}300-400 \\
\left({ }^{\circ} \mathrm{C}\right)\end{array}$ & $\begin{array}{c}400-500 \\
\left({ }^{\circ} \mathrm{C}\right)\end{array}$ & $\begin{array}{c}500-600 \\
\left({ }^{\circ} \mathrm{C}\right)\end{array}$ & \\
\hline Anadenanthera colubrina & 9.23 & $\mathrm{I} .07$ & 18.62 & 40.46 & 5.63 & 3.56 & 21.43 \\
\hline Poincianella pyramidalis & 8.82 & 1.85 & 18.85 & 37.17 & 6.57 & 4.61 & 22.13 \\
\hline Cnidoscolus quercifolius & 9.26 & 1.08 & 21.71 & 32.38 & 10.25 & 7.92 & 17.40 \\
\hline Piptadenia stipulacea & 6.56 & 0.72 & 20.72 & 42.39 & 6.89 & 6.23 & 16.49 \\
\hline Mimosa tenuiflora & 9.55 & $1.2 \mathrm{I}$ & 17.32 & 35.13 & 6.27 & 3.62 & 26.90 \\
\hline Manihot carthaginensis & 9.46 & 1.43 & 16.48 & 35.63 & 5.62 & 2.93 & 28.45 \\
\hline Aspidosperma pyrifolium & 8.51 & 0.86 & 19.87 & 38.07 & 4.98 & 2.66 & 25.05 \\
\hline Platycyamus regnellii & 7.63 & 0.49 & 19.95 & 41.68 & 5.91 & 5.54 & 18.80 \\
\hline Jatropha grossidentata & 8.05 & 2.01 & 20.85 & 36.47 & 6.84 & 4.86 & 20.92 \\
\hline Commiphora leptophloeos & 8.60 & 0.11 & 20.09 & 40.03 & 3.93 & 2.12 & 25.12 \\
\hline Average & 8.57 & 1.08 & 19.45 & 37.94 & 6.29 & 4.41 & 22.27 \\
\hline
\end{tabular}

leptophloeos species presented the highest values for total extractive content in the wood (>20\%). These values can be considered quite high when compared, for example, with the average value of $5 \%$ for woods from four Eucalyptus clones analyzed by Santos et al. (20 I I).

The highest value of lignin content (Table 2), commonly associated with charcoal yield, was observed for Mimosa tenuiflora, and Cnidoscolus quercifolius, Jatropha grossidentata, and Commiphora leptophloeos had the second highest lignin content. However, lignin content alone cannot determine the potentiality of a tree species for charcoal production (Wang et al., 2017); it is also necessary to analyze the density, dry mass yield, and chemical characteristics of the wood.

High lignin contents tend to result in high charcoal yields (Protásio et al., 2012; Wang et al., 2017). Vale et al. (2010), in an experiment with Brazilian Cerrado species, found lignin contents varying from 25.16 to $32.31 \mathrm{wt}$ \% Costa et al. (2014), in a study evaluating five Cerrado wood species, reported lignin contents of 19.88 to $26.87 w t . \%$. Protásio et al. (2013) found lignin values varying between 28.01 and $35.12 w t . \%$ for eucalyptus specimens that had similar characteristics to the species analyzed in the present study. On the basis of literature results, we highlight the potential of Mimosa tenuiflora for charcoal production.

The species Piptadenia stipulacea and Commiphora leptophloeos presented the lowest ash contents, whereas Poincianella pyramidalis had the highest percentage of ash (Table 2 and Figure 2). Paes et al. (2013) evaluated three wood species from the Caatinga and reported ash contents of less than 2.10wt.\%. A high ash content can result in equipment damage and increases the cleaning frequency required for systems that use wood as an energy source. The ash contents observed in the present study (Table 2) were low and did not compromise the energy potential of the wood. Comparison of the ash content of the studied wood species with other fuels used in Brazil for power generation evidences the advantages of Caatinga tree species. Ash contents of $5 \mathrm{wt} . \%$ to
$35 w t . \%$ have been reported for coal, a non-renewable fuel widely used for electricity generation and reduction of iron ore (Ward et al., 2008; Wang et al., 20 I I; Wang et al., 20I2; Magdziarz and Wilk, 20I3). Sugarcane bagasse, an important energy source for Brazilian industries, can have a mineral content of up to 2 lwt.\% (Scatolino et al., 2018), which is considerably higher than the values observed in this study for Caatinga wood.

According to Santos et al. (20II) and Telmo and Lousada (20lla; 20I Ib), the calorific value is an important property of wood fuels, as it expresses the amount of energy released as heat when the material undergoes complete combustion. The calorific value of wood species is influenced mainly by their chemical composition, particularly in relation to extractives, lignin and ash contents (Demirbas, 200I; Telmo and Lousada, $20 \mathrm{lla}$; Telmo and Lousada, 20l lb). This fact was in satisfactory agreement with the high higher calorific value, high lignin content and lower ash content of Mimosa tenuiflora and Cnidoscolus quercifolius woods.

The chemical composition of extractives, as well as their thermal stability, can affect charcoal yield (Protásio et al., 2012). A high ash content is not desirable, as it results in charcoal of high mineral content and may compromise the calorific value of this bio-reducer (Soares et al., 20I4). Santos et al. (20I2) obtained values of 18.59 $\mathrm{MJ} \mathrm{kg}^{-1}$ for catingueira (Poincianella pyramidalis) wood, a result similar to that found in this study. Considering that eucalyptus wood, which is widely used for power generation, has an average higher heating value of 19 MJ kg-1 (Couto et al., 20l3; Protásio et al., 2013), the results of this study demonstrate the suitability of native species of the Brazilian semi-arid region of the state of Pernambuco as fuels for heat generation.

With regard to carbonization yields, Mimosa tenuiflora, Manihot carthaginensis, and Platycyamus regnellii woods achieved the best results (Table 2). Poincianella pyramidalis and Piptadenia stipulacea had the best yields in pyroligneous liquid and were thus considered potential 
species for extraction of this product. Overall, these results show that Poincianella pyramidalis, Piptadenia stipulacea, Mimosa tenuiflora, Manihot carthaginensis, and Platycyamus regnellii had the lowest mean yield in non-condensable gases. These results are in agreement with those obtained by Oliveira et al. (2006) for Mimosa tenuiflora, Poincianella pyramidalis, Manihot carthaginensis, and Platycyamus regnellii but are lower than the yields reported by the authors for Mimosa tenuiflora wood, which ranged from 37.82 to $41.06 w t . \%$ for charcoal and from 30.56 to 34.3 I wt.\% for pyroligneous liquid.

Pereira et al. (2013) stated that the lignin syringyl/ guaiacyl $(S / G)$ ratio should be low for a high charcoal yield, as it implies a more condensed lignin structure. This may explain why woods of high lignin content do not always result in high charcoal yields. A high concentration of extractives of low thermal resistance can also lead to low charcoal yields (Poletto et al., 2012; Poletto, 2016).

In carbonization processes aimed at charcoal production, companies expect to obtain the highest charcoal yields, because, in most cases, gases are not recovered for other uses and account as losses. The yields in charcoal, pyroligneous liquid, and non-condensable gases are affected by carbonization conditions and chemical and physical characteristics of the wood (Oliveira et al., 2006; Vale et al., 20I0; Protásio et al., 20l4b).

The wood species had a similar mass loss profile in the TG curves (Figure 3). Two main thermal events can be observed: a drying phase (elimination of moisture) and a thermal degradation phase. In stage I, occurs evaporation of the water (drying), and in the second stage, between $200^{\circ} \mathrm{C}$ to $400^{\circ} \mathrm{C}$, the mass decreases rapidly due mainly to the thermal degradation of the carbohydrates (holocellulose). From $400^{\circ} \mathrm{C}$ the mass decreases less intensely due to the decomposition of the lignin macromolecule and carbonization products (Yang et al., 2007; Protásio et al., 20 I4a). According to Yang et al. (2007) and Pereira et al. (2013), no specific lignin degradation range is detected in TGA analysis, due the wide temperature ranges of the thermal decomposition of lignin. Thus, there is loss of mass of the lignin macromolecule in the other stages of thermal decomposition.

These observations are consistent with the results obtained by Elyounssi et al. (20I2), Carneiro et al. (20I3) and Protásio et al. (20I4a). With respect to DTG curves, the thermograms show peaks at approximately $80^{\circ} \mathrm{C}$, representing the drying phase. However, in spite of similarities, differences in the temperatures of maximum degradation are evident, mainly related to the degradation of hemicellulose and cellulose. With the exception of the DTG curves for Cnidoscolus quercifolius and Manihot carthaginensis, it is possible to observe an attenuation in degradation rate between $250^{\circ} \mathrm{C}$. The maximum rate of decomposition was observed in $350^{\circ} \mathrm{C}$ and correspond the thermal degradation of the cellulose. The peak of the DTG curve indicates when the cellulose degradation rate starts to decrease. At $270-300^{\circ} \mathrm{C}$, the degradation rate starts to increase again, which is indicated in the graphs by an arrow. The first temperature range corresponds to the final phase of hemicellulose degradation, and the second temperature range is attributed to cellulose degradation. For all species, stabilization of the degradation rate occurs at approximately $400^{\circ} \mathrm{C}$, which corresponds to the end of cellulose degradation, according to Yang et al. (2007) and Azizi et al. (20I7).

The studied wood species had an average mass loss of $1.08 \%$ between 100 and $200^{\circ} \mathrm{C}$, a very small mass variation. This temperature interval is known as the range of thermal stability of wood, being limited by the initial temperature of thermal decomposition of its main components (Raad et al., 2006; Yang et al., 2007). Carneiro et al. (2013) reported similar values in this temperature range to those of the present study for the average mass loss of wood species from the Caatinga of Rio Grande do Norte, Brazil. From 200 to $300^{\circ} \mathrm{C}$, the average mass loss was 19.4wt.\%. This phase probably comprises the thermal decomposition of hemicelluloses. Santos et al. (2012) observed mass losses of 16 to $19 \mathrm{wt} . \%$, between 200 and $300^{\circ} \mathrm{C}$, which is in agreement with the values obtained in the present study. The highest average mass losses occurred in the ranges of $300-400^{\circ} \mathrm{C}$ and 400 $500^{\circ} \mathrm{C}$, corresponding to a variation of 37.94 and $6.29 \%$ in wood weight, respectively, totaling $44.23 \%$. This finding can be explained by the fact that the peak mass loss for cellulose occurs at a higher temperature than that of hemicelluloses, as cellulose requires a great amount of energy for chain depolymerization and degradation of monomers (Liao, 2003; Fernandez et al., 2019).

Cnidoscolus quercifolius and Mimosa tenuiflora suffered a less pronounced mass loss in this temperature range. This interesting finding may be related to their chemical composition, as these two species had the highest lignin contents among the studied wood species. On the basis of these results, Mimosa tenuiflora can be regarded as a species of great thermal resistance and high charcoal yield (Table 2). These properties can be related to the resistance of lignin to thermal effects, which enhances the transformation of wood into charcoal.

Residual mass values varied from $16.49 \mathrm{wt} . \%$ for Piptadenia stipulacea to $28.45 \mathrm{wt} . \%$ for Manihot carthaginensis, indicating that the studied species had 
different resistances to thermal degradation. Some of the species evaluated in this study were more thermally resistant than the 7-year old eucalyptus specimens evaluated by Santos et al. (2012) by TGA. The authors reported an average residual mass of $14.75 \mathrm{wt} . \%$. Interestingly, the species Piptadenia stipulacea, which had the lowest residual mass, had the lowest ash content.

Regarding the potential for charcoal production, the results of the present study demonstrate the low contribution of cellulose to charcoal yield. Moreover, other studies have shown that the residual mass of cellulose ranges from 5 to $10 \mathrm{wt} . \%$ at $450^{\circ} \mathrm{C}$ (Yang et al., 2007; Shen and Bridgwater, 2010; Fernandez et al., 2019). Lignin does not have a specific degradation peak, because its thermal decomposition occurs over a wide range of temperatures, that is, its degradation occurs at a slow and steady rate. When considering the use of these species for charcoal production, attention must be paid to the chemical composition of wood (lignin content) as well as to variables of the production process. It is important to highlight that $450^{\circ} \mathrm{C}$ is the maximum temperature recommended for charcoal production, as it provides higher yields, according to Pereira et al. (2013). The authors explained that lignin degradation is more intense at temperatures above $450^{\circ} \mathrm{C}$.

According to the results presented in Figure 3 and Table 3, the greatest mass loss for all species occurred between 300 and $400^{\circ} \mathrm{C}$. Yang et al. (2007) reported that this temperature range provides the highest thermal degradation of cellulose. The energy absorbed in the first phases of the process is related to evaporation of water from the material. The reaction becomes exothermic at approximately $300^{\circ} \mathrm{C}$ (Pereira et al., (2013), coinciding with the maximum mass loss peak (Table 3), when the greatest loss of volatile compounds occurs.

The biomass components directly influence its pyrolysis behavior, which was elucidated by TGA. This fact was demonstrated by Raad et al. (2006) and Yang et al. (2007), two studies that report the behavior of the main components of wood separately subjected to pyrolysis. Only in this manner can overlapped similarities of different constituents be distinguished at the same time (Haykiri-Acma et al., 20I0).

The second thermal event is attributed to the pyrolysis of the main wood constituents (cellulose, hemicelluloses, and lignins). Each component has a different behavior when exposed to heat. According to Yang et al. (2007), hemicelluloses begin to decompose at $220-315^{\circ} \mathrm{C}$. According to these authors, cellulose undergoes pyrolysis at a higher temperature range, between 315 and $400^{\circ} \mathrm{C}$. At temperatures above $400^{\circ} \mathrm{C}$, most cellulose has already been degraded. Lignin is the most difficult component to decompose, as its degradation occurs slowly from the beginning of carbonization of other constituents up to $900^{\circ} \mathrm{C}$ (Yang et al., 2007). Above $400^{\circ} \mathrm{C}$, the thermal degradation of wood decreases considerably, corresponding to lignin degradation. At this temperature, cellulose and hemicelluloses have already been thermally degraded.

\section{CONCLUSIONS}

Mimosa tenuiflora and Poincianella pyramidalis were the most suitable wood species for sustainable charcoal production.

The thermal decomposition profiles of wood samples obtained by TGA can aid in the selection of species of greater energy potential for charcoal production. TGA allows the control of carbonization processes on an experimental scale and the determination of the relationship between temperature and degradation of wood components. The thermal stability behavior of 10 wood species was confirmed by analysis of charcoal yield.

It is recommended specific studies that can relate the thermal decomposition in different temperature ranges and the respective gases emitted (TGA-GC/MS/ PY) to conclusions about environmental sustainability.

\section{ACKNOWLEDGEMENTS}

The authors would like to thank the Plants of the Northeast Association (APNE) for providing the wood species used in this study. This research was financially supported by CNPq (National Council for Scientific and Technological Development, Brazil) and CAPES (Higher Education Personnel Improvement Coordination, Brazil).

\section{REFERENCES}

AMAZONAS, N. T.; FORRESTER, D. I.; SILVA, C. C.; ALMEIDA, D. R. A.; RODRIGUES, R. R.; BRANCALION, P. H. S. High diversity mixed plantations of Eucalyptus and native trees: An interface between production and restoration for the tropics. Forest Ecology and Management, n. 417, p.247-256, 2018.

ARAÚJO, A. C. C.; TRUGILHO, P. F.; NAPOLI, A.; BRAGA, P. P. C.; LIMA, R. V.; PROTÁSIO, T. P. Efeito da relação siringil/ guaiacil e de fenóis derivados da lignina nas características da madeira e do carvão vegetal de Eucalyptus spp. Scientia Forestalis, v. 44, n. II0, p.405-4I4, 2016.

ASSOCIAÇÃO BRASILEIRA DE NORMAS TÉCNICAS. NBR 8I 12: carvão vegetal - análise imediata. Rio de Janeiro, 1986. $5 p$. 
ASSOCIAÇÃO BRASILEIRA DE NORMAS TÉCNICAS. NBR 8633: Carvão vegetal - Determinação do poder calorífico Método de ensaio. Rio de Janeiro, 1984. 13p.

AZIZI, K.; MORAVEJI, M. K.; NAJAFABADI, H. A. Characteristics and kinectis study of simultaneous pyrolysis of microalgae Chlorella vulgaris, wood and polypropylene through TGA. Bioresource Technology, v. 243, p. 48I-49I, 20 I7.

CARNEIRO, A. C. O.; SANTOS, R. C.; CASTRO, R. V. O.; CASTRO, A. F. N. M.; PIMENTA, A. S.; PINTO, E. M.; ALVES, I. C. N. Estudo da decomposição térmica da madeira de oito espécies da região do Seridó, Rio Grande do Norte. Revista Árvore, v. 37, n. 6, p. II53-1 I63, 2013.

COSTA, T. G.; BIANCHI, M. L.; PROTÁSIO, T. P.; TRUGILHO, P. F.; PEREIRA, A. J.; Qualidade da madeira de cinco espécies de ocorrência no cerrado para produção de carvão vegetal. Cerne, v. 20, n. I, p. 37-46, 2014.

COUTO, A. M.; PROTÁSIO, T. P.; TRUGILHO, P. F.; NEVES, T. A.; SÁ, V. A. Multivariate analysis applied to evaluation of Eucalyptus clones for bioenergy production. Cerne, v. 19, n. 4, p. 525-533, 2013.

DEMIRBAS, A. Biomass resource facilities biomass conversion processing for fuels and chemicals. Energy Conversion Management, v. 42, n. II, p.1357-1378, 2001.

DERMIBAS, A. Relationships between lignin contents and fixed carbon contents of biomass samples. Energy Conversion and Management, v. 44, n. 9, 2003. p. | |48|-| 486.

DIAS JÚNIOR, A. F.; ANDRADE, C. R.; PROTÁSIO, T. P.; MELO, I. C. N. A.; BRITO, J. O.; TRUGILHO, P. F. Pyrolysis and wood by-products of species from the Brazilian semiarid region. Scientia Forestalis, v. 46, n. I17, 2018.

ELYOUNSSI, K.; COLLARD, F. X.; NGOLLO MATEKE, J. A.; BLIN, J. Improvement of charcoal yield by two-step pyrolysis on eucalyptus wood: A thermogravimetric study. Fuel, v. 96, p.161-167, 2012.

FERNANDEZ, A.; SORIA, J.; RODRIGUEZ, R.; BAEYENS, J.; MAZZA, G. Macro-TGA steam-assistet gasification of lignocellulosic wastes. Journal of Environmental Management, v. 233, p. 626-635, 2019.

GUILLÉN, M. D.; MANZANOS, M. J.; IBARGOITIA, M. L. Carbohydrate and nitrogenated compounds in liquid smoke flavourings. Journal of Agricultural and Food Chemistry, Davis, v. 49, n. 5, p. 2395-2403, 200 I.

JESUS, M.; NAPOLI, A.; TRUGILHO, P. F; ABREU JÚNIOR, A. A.; MARTINEZ, C. L. M.; FREITAS, T. P. Energy and mass balance in the pyrolysis process of eucalyptus wood. Cerne, v. 24, n. 3, p. 288-294, 2018.

KELTY, M. J. The role of species mixtures in plantation forestry. Forest Ecology Management, v. 233, n. 3, p. 195-204, 2006.
HAYKIRI-ACMA, H.; YAMAN, S.; KUCUKBAYRAK, S. Comparison of the thermal reactivities of isolated lignin and holocellulose during pyrolysis. Fuel Processing Technology, v. 9I, p.759-764, 2010.

LIAO, Y. F. Mechanism study of cellulose pyrolysis. Thesis (Phd Report) Zhe Jiang University, HangZhou, China, 2003.

MAGDZIARZ, A; WILK, M. Thermogravimetric study of biomass, sewage sludge and coal combustion. Energy Conversion and Management, Amsterdam, v.75, p.425430, 2013.

MARTINEZ, M. G.; DUPONT, C.; THIÉRY, S.; MEYER, X. M.; GOURDON, C. Impact of biomass diversity on torrefaction: study of solid conversion and volatile species formation through an innovative TGA-GC/MS apparatus. Biomass and Bioenergy, v. II9, p.43-53, 2018.

MÜLLER-HAGEDORN, M. et al. A comparative kinetic study on the pyrolysis of three different wood species. Journal of Analytical and Applied Pyrolysis, v. 68, n. I, p.23I-249, 2003.Identificar autores

OLIVEIRA, E.; VITAL, B. R.; PIMENTA, A. S.; DELLA LUCIA, R. M.; LADEIRA, A. M. M.; CARNEIRO, A. C. O. Estrutura anatômica da madeira e qualidade do carvão de Mimosa tenuiflora (Willd.) Poir. Revista Árvore, Viçosa, v.30, n.2, p.3|I-3|8, 2006.

PAES, J. B.; LIMA, C. R.; OLIVEIRA, E.; HERIC CAVALCANTI MASCARENHAS DOS SANTOS, H. C. M. Rendimento e caracterização do carvão vegetal de três Espécies de ocorrência no semiárido brasileiro. Ciência da Madeira, Pelotas, v. 03, n. 01, p.0I-10, 2012

PAES, J. B.; LIMA, C. R.; OLIVEIRA, E.; MEDEIROS NETO, P. $N$. Características físico-química, energética e dimensões das fibras de três espécies florestais do semiárido brasileiro. Floresta e Ambiente, v. 20, p.550-555, 2013.

PEREIRA, B. L. C.; CARNEIRO, A. C. O.; CARVALHO, A. M. L. L.; TRUGILHO, P. F.; MELO, I. C. N. A.; OLIVEIRA, A C. Estudo da degradação térmica da madeira de Eucalyptus através de termogravimetria e calorimetria. Revista Árvore, v. 37, n. 3, p.567-576, 2013.

PEREIRA, B. L. C.; CARNEIRO, A. C. O.; CARVALHO, A. M. M. L.; COLODETTE, J. L.; OLIVEIRA, A. C.; FONTES, M. P. F. Influence of chemical composition of Eucalyptus wood on gravimetric yield and charcoal properties. Bioresources, Railegh, v. 8, p.4574-4592, 2013.

POLETTO, M.; ZATTERA, A. J.; FORTE, M. M. C.; SANTANA, R. M. C. Thermal decomposition of wood: Influence of wood components and cellulose crystallite size. Bioresource Technology, v. 109, p. I48-153, 2012.

POLETTO, M. Effect of extractive content on the thermal stability of two wood species from Brazil. Maderas. Ciencia y tecnología, v. 18, n. 3, p.435-442, 2016. 
PROTÁSIO, T. P.; TRUGILHO, P. F;; NEVES, T. A.; VIEIRA, C. M. M. Análise de correlação canônica entre características da madeira e do carvão vegetal de Eucalyptus. Scientia Forestalis, Piracicaba, v. 40, n. 95, p. 317-326, 2012.

PROTÁSIO, T. P.; COUTO, A. M.; REIS, A. A.; TRUGILHO, P. F; GODINHO, T. P. Potencial siderúrgico e energético do carvão vegetal de clones de Eucalyptus spp. aos 42 meses de idade. Pesquisa Florestal Brasileira, v. 33, n. 74, p. |37-|49, 2013.

PROTÁSIO, T. P.; TRUGILHO, P. F.; CÉSAR, A. A. S.; NAPOLI, A.; MELO, I. C. N. A. ; SILVA, M. G. Babassu nut residues: potential for bioenergy use in the North and Northeast of Brazil. SpringerPlus, v. 3, n. I24, p. I-I4, 20I4a.

PROTÁSIO, T. P.; TRUGILHO, P. F.; NAPOLI, A.; SILVA, M. G.; COUTO, A. M. Mass and energy balance of the carbonization of babassu nutshell as affected by temperature. Pesquisa Agropecuária Brasileira, v. 49, n.3, p. 189-196, 2014b.

RAAD, T. J.; PINHEIRO, P. C. C.; YOSHIDA, M. I. Equação geral de mecanismos cinéticos da carbonização do Eucalyptus spp. Cerne, v. I2, n. 2, p.93-106, 2006.

ROWELL, R. M. et al. Cell wall chemistry. In: ROWELL, R.M. (Ed.). Handbook of wood chemistry and wood composites. Boca Raton: CRC Press, 2005. p. I 2 I-1 38.

SANTOS, R. C.; CARNEIRO, A. C. O.; CASTRO, A. F. M.; CASTRO, R.V. O.; BIANCHE, J. J.; SOUZA, M. M. Correlações entre os parâmetros de qualidade da madeira e do carvão vegetal de clones de eucalipto. Scientia Forestalis, v. 39, n. 90, p.221-230, 201 I.

SANTOS, R. C.; CARNEIRO, A. C. O.; TRUGILHO, P. F; MENDES, L. M.; CARVALHO, A. M. M. L. Análise termogravimétrica em clones de eucalipto como subsídio para a produção de carvão vegetal. Cerne, v. 18, n. I, p. |43-|5|, 2012.

SCATOLINO, M. V.; CABRAL NETO, L. F. C.; PROTÁSIO, T. P.; CARNEIRO, A. C. O.; ANDRADE, C. R.; GUIMARÃES JUNIOR, J. B.; MENDES, L. M. Options for Generation of Sustainable Energy: Production of Pellets Based on Combinations Between Lignocellulosic Biomasses. Waste and Biomass Valorization, v. 9, n. 3, p. 479-489, 2018.

SHEN, R.; GU, S.; BRIDGWATER, A. V. The thermal performance of the polysaccharides extracted from hardwood: Cellulose and hemicelluloses. Carbohydrate Polymers, v. 82, p.39-45, 2010.
SILVA, J. M. C.; D. C. OREN. Geographic variation and conservation of the Moustached Woodcreeper (Xiphocolaptes falcirostris), na endemic and threatened species of Northeastern Brazil. Bird Conservation International, n. 7, p.263-274, 1997.

SJÖSTRÖM, E. Wood chemistry - fundamentals and applications. London: Academic Press, 1993. 293p.

SOARES, V. C.; BIANCHI, M. L.; TRUGILHO, P. F.; JÚNIOR PEREIRA, A.; HÖFLER, J. Correlações entre as propriedades da madeira e do carvão vegetal de híbridos de eucalipto. Revista Árvore, v.38, n.3, p.543-549, 2014.

TECHNICAL ASSOCIATION OF PULP AND PAPER. TAPPI. Industry lignin in wood. 1998. (TAPPI I 2 05-75).

TECHNICAL ASSOCIATION OF PULP AND PAPER. TAPPI. Industry preparation of wood for chemical analysis (Including procedures for removal of extractives and determination of moisture content). 1998. (TAPPI I 2 05-75).

TELMO, C.; LOUSADA, J. Heating values of wood pellets from different species. Biomass and Bioenergy, v.35, n.7, p.2634-2639, 20I la.

TELMO, C.; LOUSADA, J. The explained variation by lignin and extractive contents on higher heating value of wood. Biomass and Bioenergy, v. 35, n. 5, p.1663-I667, $20 \mathrm{Il} \mathrm{lb.}$

VALE, A. T.; DIAS, I. S.; SANTANA, M. A. E. Relações entre propriedades químicas, físicas e energéticas da madeira de cinco espécies de cerrado. Ciência Florestal, Santa Maria, v.20, n.I, p.I37-I45, 2010

YANG, H.; YAN, R.; CHEN, H.; LEE, D. H.; ZHENG, C. Characteristics of hemicellulose, cellulose and lignin pyrolysis. Fuel, v. 86, p. I78I-I788, 2007.

WANG, C.; LIU, Y.; ZHANG, X. CHE, D. A study on coal properties and combustion characteristics of blended coals in northwestern China. Energy \& Fuels, v. 25, p.3634$3645,201 \mathrm{I}$.

WANG, C.; LIU, Y.; ZHANG, X. CHE. Pyrolysis and combustion characteristics of coals in oxyfuel combustion. Applied Energy, v. 97, p. 264-273, 2012.

WANG, S.; DAI, G.; YANG, H.; LUO, Z. Lignocellulosic biomass pyrolysis mechanism: A state-of-the-art review. Progress in Energy and Combustion Science, v.62, p.33-86, 2017.

WARD, C. R.; ZHONGSHENG, L.; GURBA, L. W. Comparison of elemental composition of materials determined by electron microprobe to whole-coal ultimate analysis data. International Journal of Coal Geology, v.75, p. I57-I65, 2008. 